\title{
PREDICTION OF TRACTOR FUEL CONSUMPTION AND DRAWBAR POWER USING LABORATORY AND FIELD TESTS
}

Bahnasy, A F $\mathbf{F}^{\mathbf{1}}$;

A A. El-Gwadi and ${ }^{2}$

M E. M. Morsi ${ }^{3}$

\section{ABSTRACT}

Recent increases in fuel prices have generated another cost concern for farmers. Fuel is one of several input costs that have continued to increase over the years with fuel prices taking a dramatic prices jump over a short time period Therefore; an indirect method of indicating drawbar pull by measuring tractor fuel consumption, power take off and engine speed during field operation are described. The aim of this work study was to study factors which may help to reduce the tractor rate of fuel consumption, and to define a predicted formula for power exerted on the draw-bar using both power take off; and draw bar laboratory tests, and compare those gained result with formula defined by Grrisso. In this work study a tractor of $26 \mathrm{~kW}$ was tested using both PTO dynamometer for factors affecting on tractor power take off shaft, and a drawbar dynamometer for factors affecting on tractor draw-bar. Meanwhile an equation for pull prediction was figured out using power on the power take off; engine speed; fuel consumption; and the forward speed factors. No significant differences were found between this formula and Grrisso formula. Throttle down and gear up is recommended during $75 \%$ and 50 $\%$ drawbar load.

\section{INTRODUCTION}

ear Up and Throttle Down" is a fuel-saving practice suitable for light drawbar loads (less than 65 percent of full power) when reduced PTO speed is not a problem For the most efficient operation, a tractor's engine should be operated near its rated capacity. However, would be done there are many field operations (such

${ }_{3}^{12}$ Senior Researcher, Agric. Eng. Res. Inst. Dokki Giza

${ }^{3}$ Researcher, Agric. Eng. Res. Inst. Dokki Giza 
as light tillage, planting, cultivating, and hay raking) that do not require full tractor power. This is especially true when older time implements, which were sized for a smaller tractor, are used with higher horsepower tractors. Also, many operations should be performed at a fixed field speed. For these lighter operations, a substantial amount of fuel can be saved by shifting to a faster gear and slowing the engine speed to maintain the desired field speed, or "Gear Up and Throttle Down." An example of this Energy procedure is shifting a manual transmission car or truck from second to third gear while reducing the throttle setting to maintain travel speed.

Elashry (2002) used a separated apparatus for fuel consumption. It was installed and connected to tractor fuel tank through hoses and two 2-way valves. The secondary tank was first filled with fuel to the mark on the top of the tab. During the actual run, the tractor was first let go on its fuel from the main tank. To measure the fuel consumption during a specific field operation, the secondary tank was utilized through the valve (1) and (2).at the end of the run, the valves were refilled off. The secondary tank was refilled to the mark on the tube from a graduated cylinder and amount of refuel was taken as fuel consumption during the specific operation duration.

El-Sayed and Rushdie (2002) Reported that accurate measurement of fuel consumption in the field is very expensive and difficult. Computer simulation is more efficient but need a universal method to calculate predicted fuel consumption during different work condition. They predicted tractor fuel consumption for different agricultural operations; the method is based on energy requirement to the machine in particular field operation and the total tractor efficiency.

Nada (2003) developed an electronic continuous mass fuel measuring system in the laboratory and during the power take off test of tractor. The system included four strain gauges installed in a cantilever beam, two strain gauges on the top surface and two strain gauges on the bottom surface and connected with a data modules and interfaced with a laptop computer to display and store data. 
Mohamed and Bahnasy (2005) developed fuel measuring instrument. The developed fuel measuring instrument is simple and inexpensive to construct, easy to use, and suitable for most field research. Comparing the developed instrument with the customary instrument, the use of the designed instrument avoid the human errors which happened when the bulb valves are used or when switching on or off the stop watch during the test run using the customary instrument. This fuel instrument can provide researchers with an expensive method of determining fuel used under field and laboratory conditions.

Romanov et al., (2005) made an analysis of the functioning and accuracy of piston-type flow meters for measuring fuel consumption by tractor engines. Acceptable accuracy can be achieved, provided that there is a gap (play) between the tube wall and the piston. Measuring error is smallest when the density of the piston is similar to that of the fuel. Measuring error caused by pulsations in fuel consumption is small, and can be significantly reduced by the correct combination of piston mass and radius.In literatures there was different information about models to predict fuel consumption during field operations. To determine the average fuel consumption of a tractor operating under arrange of load conditions, over a period of time, refer to ASAE EP496

Diesel:

$$
\mathrm{FC}=2.64 \mathrm{X}+3.91-0.203 \sqrt{738 \mathrm{X}+173}
$$

Where:

$$
\begin{gathered}
\mathrm{X}=\text { The ratio of equivalent PTO power required by an } \\
\text { operation to that maximum available from the PTO. }
\end{gathered}
$$

Average annual fuel consumption for a specific make and model tractor can be approximated from the Nebraska Tractor Test Data. Average gasoline consumption over a whole year can be estimated by the following formula:

Where:

$$
\mathrm{Q}_{\text {avg }}=0.305 \times \mathrm{P}_{\text {pto }}
$$

Qavg = average gasoline consumption, $\mathrm{L} / \mathrm{h}$ :

$\mathrm{P}$ pto $=$ maximum $\mathrm{PTO}$ power, $\mathrm{kW}$. 
Since most tractors tested and used for agricultural purposes in the last 25 years have had diesel engines which use approximately $73 \%$ as much fuel in volume as a gasoline tractor, the above equation converted for diesel engines becomes:

$$
\mathrm{Q}_{\text {avg }}=0.305 \times 0.73 \times \mathrm{P}_{\text {pto }}
$$

The objectives of this study are:

- To identify factors affecting the fuel consumption and drawbar pull in agricultural tractors.

- To develop a model predicting drawbar pull during field operations.

- $\quad$ To test the developed models with data obtained and with previous model.

\section{MATERIALS AND MEATHODS}

\section{Martial}

\section{Tractors}

Two tractors were used in this study having the same power and weight, one of them was used as loading tractor the other was used for the test. Technical specifications of the tractor diesel engine are a 2-cylinder, Helwan 35-IMT of maximum power $26.12 \mathrm{~kW}$ at $2200 \mathrm{rpm}$. The bore $\mathrm{x}$ stroke is $105 \mathrm{~mm} \times 125 \mathrm{~mm}$, where the compression ratio is $16: 1$, engine rated speed $1800 \mathrm{rpm}$.

\section{PTO dynamometer:}

The PTO dynamometer was made in U.S.A and has the following specification:

Model:

Nebraska 200

Torque rating (Ft.Lbs \& N.m): 10001355

RPM range (pto \& engine): $0-3600$

\section{Data acquisition system}

A Daytronic data PAC model 10k4 capable to convert the voltage signal to the desired SI units, and Hewlett Packard model 110 laptop computer were used for calibration and for field data collection.. The Data PAC unit conditioned the output signal into proper engineering units. The 
computer was used to store incoming data and communicate with the data PAC.

\section{Strain gage Pull dynamometer}

Draw bar pull measured by using strain gage pull dynamometer. The calibration hydraulic dynamometer was used to as reference to calibration the pull meter strain gage. The strain gage pull meter was connected with. And applied in equal steps from no load to the maximum allowed load and then reduced load approximately in the same steps back to no load.

\section{Rotational speed}

Fig. (1) shows the constructed mechanism used to measure PTO speed during field tests. It consists of a gear with 60 teeth, a magnetic pickup and a digital rpm meter. The gear was fixed to tractor PTO and the magnetic pickup generated impulse signals as the PTO shaft rotated. These signals indicated PTO rpm on the digital read-out which fixed at front of the tractor's operator. The measured PTO speed was converted to engine torque and specific fuel consumption with the use of regression equations.

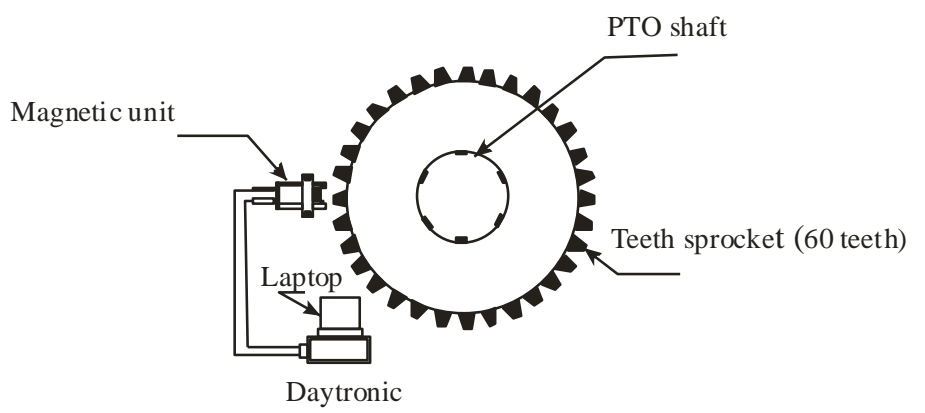

Fig.(1): The mechanism used to measure PTO speed during field test.

\section{Methods}

This indirect measurement of diesel fuel consumption rate is accomplished by measuring of power take off, draft and engine speed during field operation. The specific subscript refers to the location of the test, where the tractor test conducted at full throttle, and reduced throttle during the $50 \%$ and $75 \%$ drawbar load tests. The method used the fuel consumption data, power levels and engine speed from 4 part load 
drawbar load tests and the PTO and drawbar power at rated engine speed. The equivalent power ratios (at the 4 test points) were computed from maximum drawbar power at rated engine speed and the current power level.

Grisso et al (2004) developed an equation to evaluate the fuel consumption of a tractor at any engine speed and partial load:

$$
Q(L / h)=(0.22 X+0.096)\left[1-\left(-0.0045 X . N_{\text {red }}+0.00877 N_{\text {red }}\right] P_{p t o} \quad 1\right.
$$

Being $X$ the ratio between the power at any partial load and the rated power, Nred the percentage of reduced engine speed for a partial load from full throttle $(\%)$ and $\mathrm{P}_{\text {pto }}$ the rated power $(\mathrm{kW})$ measured at the power-take-off. The method for developing the generalized model (Eq.1) was used to develop specific coefficients for specific tractor models. The coefficients used the Nebraska Tractor test results and the defining locations of the various parameters Grisso et al. (2006) the equation for a specific tractor is defined as:

$\mathrm{Q}=(\mathrm{aX}+\mathrm{b})\left(1+\left(\mathrm{cXN} \mathrm{N}_{\text {Red }}-\mathrm{dN} \mathrm{N}_{\text {Red }}\right)\right)$ Ppto

Where:

$$
\begin{aligned}
& \left.\mathrm{a}=\left(\mathrm{Q}_{75 \mathrm{f}^{-}} \mathrm{Q}_{50 \mathrm{~F}}\right) / \mathrm{P}_{\mathrm{pto}}\left(\mathrm{X}_{75 \mathrm{~F}^{-}} \mathrm{X}_{50 \mathrm{~F}}\right)\right) \\
& \mathrm{b}=((\mathrm{q} 75 \mathrm{~F} / \mathrm{Ppto})-\mathrm{aX} 75 \mathrm{~F} \\
& \mathrm{c}=(\mathrm{f} / \mathrm{h}-\mathrm{e} / \mathrm{g}) /(\mathrm{X} 75 \mathrm{~F}-\mathrm{X} 50 \mathrm{~F}) \\
& \mathrm{d}=\mathrm{c} \cdot \mathrm{X} 50 \mathrm{~F}-\mathrm{f} / \mathrm{h} \\
& \mathrm{e}=1-\left((\mathrm{X} 75 \mathrm{~F}-\mathrm{Q} 75 \mathrm{R}) /\left(\mathrm{X} 75 \mathrm{R}^{*} \mathrm{Q} 75 \mathrm{~F}\right)\right) \\
& \mathrm{f}=1-\left((\mathrm{X} 50 \mathrm{~F}-\mathrm{Q} 50 \mathrm{R}) /\left(\mathrm{X} 50 \mathrm{R}^{*} \mathrm{Q} 50 \mathrm{~F}\right)\right) \\
& \mathrm{g}=(\mathrm{RPM} 75 \mathrm{~F}-\mathrm{RPM} 75 \mathrm{R}) * 100 / \mathrm{RPM} 75 \mathrm{~F} \\
& \mathrm{Q}=\text { diesel fuel consumption, } \mathrm{L} / \mathrm{h}(\mathrm{gal} / \mathrm{h}) \\
& \mathrm{X}=\text { the ratio of equivalent PTO power to rated PTO power, decimal } \\
& \mathrm{RPM}=\text { the engine speed for partial loads from full and reduced throttle, rpm } \\
& \mathrm{P}_{\mathrm{pto}}=\text { the rated PTO power, } \mathrm{kW} \\
& \mathrm{h}=(\mathrm{RPM} 50 \mathrm{~F}-\mathrm{RPM} 50 \mathrm{R}) * 100 / \mathrm{RPM} 50 \mathrm{~F}
\end{aligned}
$$

The decreases in SVFC and engine speed were based on the following percentages Grisso et al. (2004): 


$$
\begin{gathered}
\text { Decrease in } S V F C=\left(\frac{S V F C_{F}-S V F C_{R}}{S V F C_{F}}\right) \times 100 \\
N_{\mathrm{Red}}=\left(\frac{R P M_{F}-R P M_{R}}{R P M_{F}}\right)
\end{gathered}
$$

Where

$\mathrm{SVFC}=$ the specific volumetric fuel consumption at full throttle (F), and reduced throttle R, during the $50 \%$ and $75 \%$ drawbar load tests, respectively, L/kW.h.

Nred $=$ the percentage of engine speed $(\mathrm{rpm})$ reduction during the $50 \%$ and $75 \%$ drawbar load tests at reducing throttle, compared to full throttle (f), respectively, \%

This measurement of diesel fuel consumption rate is accomplished by measuring of power take off, draft and engine speed during field operation. Data of power and fuel consumptions were obtained from tests performed at several fields reports for testing tractor according to the OECD codes.

\section{Power-take off-test}

Power, engine speed and fuel consumption at full throttle at different partial loads were recorded.

\section{Experimental procedures}

\section{Laboratory tests}

The tractor was tested in the laboratory of Testing and Research Station for Tractors and Agricultural Machinery Alexandria, Egypt according to Nebraska tests. A PTO dynamometer was used to load the tractor during the laboratory tests. The PTO speed, torque and fuel consumption were recorded. Measuring was done on 20 points starting from $900 \mathrm{l} / \mathrm{min}$ up to $27001 /$ min engine speed. Before taking data from these points, observations have to wait for a particular period until the engine was stable. The maximum power value obtained was regarded as maximum PTO power. Fuel consumption per hour was also measured while determining engine power. By considering the power values of the same test, specific fuel consumption and fuel consumption per hour due to engine speed could be obtained. 


\section{Drawbar pull test}

Power, pull force, travel speed, fuel consumption and slip were measures in the rated point, at travel speed close to $4 \mathrm{~km} / \mathrm{h}$. The tests were carried out at concrete road laboratory of Testing and Research Station for Tractors and Agricultural Machinery Alexandria, Egypt according to Nebraska tests. In order to load the tractor during the tests, draw bar pull was measured by using a strain gage dynamometer and two tractors. One of the two tractors was towed by the other. The rear (towed) tractor, which it's pull measured. A horizontal chain with the strain gage dynamometer linked the two tractors. The rear tractor is being in neutral condition. The draw bar pull was recorded through the Daytronic data PAC model 10k4 to lap top. This process was repeated three times. Full drawbar tests for all tractor gears are achieved the maximum drawbar pull is recorded at $2^{\text {sd }}$ gear. For the drawbar $75 \%$ and $50 \%$ of maximum pull engine speed and fuel consumption were measured, the corresponding test during reduced throttle at $3^{\text {th }}$ setting was recorded.

\section{RESULTS AND DISCATION}

\section{PTO torque and power test}

The most direct and accurate approach to produce a traction input power substitute from engine speed can be refed to as the PTO substitute method. This method requires measuring the PTO power developed as a function of engine speed at the full throttle position. The PTO power and torque curves are shown in figure (2).

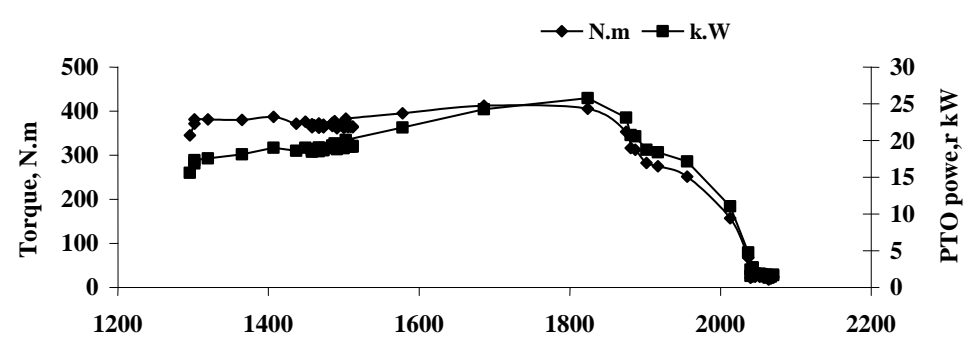

Engine Speed, R.P.M.

Fig.(2): PTO torque and power versus Engine speed . 
Table 2 shows the subscript to the location of the test, where the tractor tests were conducted at full throttle, and reduced throttle, during the 50\% and $75 \%$ drawbar load tests. Table 1 gives a summary of the coefficients of equation 1 and its values

Table (1): summary of the coefficients determined from tractor test.

\begin{tabular}{|l|c|c|c|c|c|c|c|c|}
\hline & $\mathrm{a}$ & $\mathrm{b}$ & $\mathrm{c}$ & $\mathrm{d}$ & $\mathrm{e}$ & $\mathrm{f}$ & $\mathrm{g}$ & $\mathrm{h}$ \\
\hline Individual & 0.140 & 0.025 & 0.001 & -0.002 & 0.026 & 0.075 & 19.048 & 27.273 \\
\hline
\end{tabular}

Table (2): Drawbar performance and fuel consumption characteristics

\begin{tabular}{|c|l|c|c|c|c|c|c|}
\hline Gear & & DBp & FC & V & engine rpm & DBP & X \\
\hline \multirow{2}{*}{$2^{\text {th }}$} & Drawbar test, maximum pull & 12.75 & 2.8 & 3.7 & 1880 & 17.81 & 0.77 \\
\cline { 2 - 8 } & Drawbar test, 75\% pull, full throttle & 9.56 & 2.46 & 3.75 & 1960 & 13.54 & 0.55 \\
\cline { 2 - 8 } & Drawbar test,50\% pull, full throttle & 6.37 & 1.98 & 3.8 & 1989 & 9.15 & 0.41 \\
\hline \multirow{2}{*}{$3^{\text {th }}$} & Drawbar test, 75\% pull, Red throttle & 9.56 & 2 & 3.79 & 1492 & 13.68 & 0.4 \\
\cline { 2 - 8 } & Drawbar test, 50\% pull, Red throttle & 6.50 & 1.5 & 3.89 & 1509 & 9.36 & 0.33 \\
\hline
\end{tabular}

Where:

$\mathrm{DBp}=$ draw-bar pull, $\mathrm{kN}$

$\mathrm{FC}=$ tractor fuel consumption during draw-bar test, $\mathrm{l} / \mathrm{h}$

$\mathrm{V}=$ tractor forward speed, $\mathrm{km} / \mathrm{h}$

$\mathrm{DBP}=$ draw-bar power, $\mathrm{kW}$

$\mathrm{X}=$ equivalent $\mathrm{PTO}$ power to rated PTO power, decimal

Figure (3) shows the relation between measured and predicted fuel consumption. Also the predicted values of Grisso equation is very close to measuring values which presented by $45^{\circ}$ line. Coefficient of determination $\left(\mathrm{R}^{2}\right)$ used to test both predicted with measuring fuel consumption, it could be calculated using EXCEL program. Decreasing tractor drawbar pull by $25 \%$ and $50 \%$ from the maximum pull decreased fuel consumption by $12 \%$ and $29 \%$ respectively (at full throttle). On the otherwise reducing engine speed by $20 \%$ reduced fuel consumption by $28 \%$ and $46 \%$ for drawbar pull $75 \%$ and $50 \%$ respectively (decrease fuel throttle). The reduction on fuel consumption refers to reducing engine speed. The forward operating speed of $3.07 \mathrm{~km} / \mathrm{h}$ was mounted by 
engage to higher gear. The regression analysis between observed and predicted fuel consumption can be expressed as follows:-

$$
\mathrm{Y}=1.0739 \mathrm{X} \quad \mathrm{R}^{2}=0.9372
$$

Where:

$\mathrm{Y}=$ predicted fuel consumption, $\mathrm{l} / \mathrm{h}$

$\mathrm{X}=$ observed fuel consumption, $1 / \mathrm{h}$

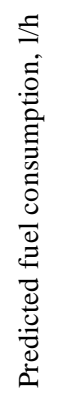

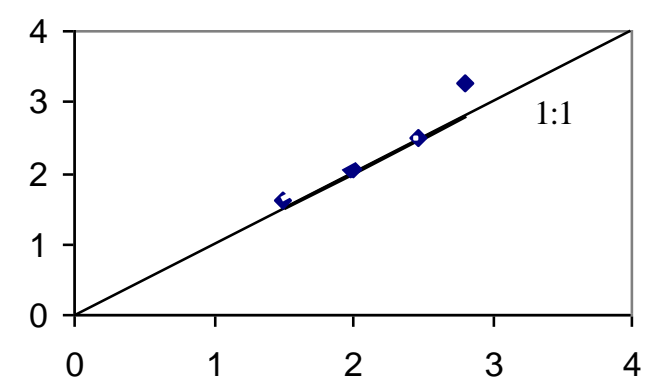

Obseved fuel consumption, $1 / \mathrm{h}$

Fig.(3): Observed fuel consumption versus predicted fuel consumption

\section{Drawbar power}

The following driving equation from data under study showed predicted drawbar power as a function in engine rpm, fuel consumption and tractor forward speed.

$\mathrm{DBP}=\beta_{1} * \mathrm{FC}+\beta_{2} * \mathrm{~V}+\beta_{3} * \mathrm{RPM}+\beta_{4}$

Where:

$\mathrm{FC}=$ tractor fuel consumption. $\mathrm{L} / \mathrm{h}$

$\mathrm{V}=$ forward speed, $\mathrm{km} / \mathrm{h}$

RPM= engine speed revolution per minute

$\beta_{1}, \beta_{2}, \beta_{3}, \beta_{4}=$ regression constant.

Two methods were used for predicting drawbar power. The first one (method1) used measured fuel consumption, engine rpm and forward speed as a function on drawbar power. Second method (mthod2) used the same pervious factors except the fuel consumption which changed by predicted one. Table (3) shows the values of the constants on the method1, method 2 and its coefficient of determination $\left(R^{2}\right)$. Figure (4) 
represent observed drawbar power versus predicted drawbar power (DBP1) using measured fuel consumption and predicted drawbar power (DBP2) using predicted fuel consumption.

Table (3): Regression coefficients $\left(\beta_{1}, \beta_{2}, \beta_{3}, \beta_{4}\right)$ and coefficient of determination $\left(\mathrm{R}^{2}\right)$ of two methods for equation 2 .

\begin{tabular}{|l|l|l|l|l|l|}
\hline & $\beta_{1}$ & $\beta_{2}$ & $\beta_{3}$ & $\beta_{4}$ & $\mathrm{R}^{2}$ \\
\hline Method1 & 10.41 & 9.09 & -0.00944 & -27.4129 & 0.997 \\
\hline Method2 & 4.0925 & -26.6888 & -0.00798 & 118.4459 & 0.989 \\
\hline
\end{tabular}

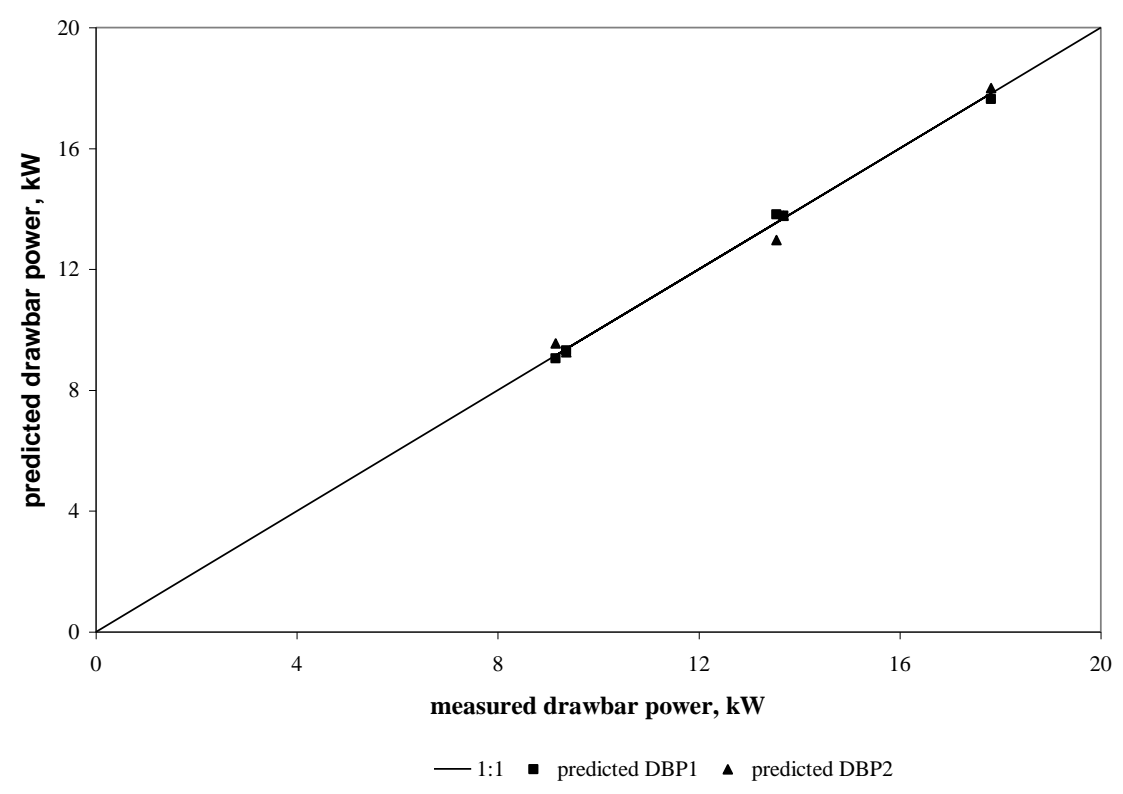

Fig. (4): Relationship between measured and predicted drawbar power derived from observed and predicted fuel consumption.

\section{CONCLUSION}

The following conclusion could be obtained:

1. Grisso equation could be used to predict fuel consumption.

2. The developed statistical models predict drawbar power using multiple regression analysis as a function of fuel consumption, forward speed and engine speed could be used with low relative error compared with measured value. 
3. Reducing engine speed during drawbar load $75 \%$ and $50 \%$ decreased fuel consumption by $28 \%$ and $46 \%$ respectively.

4. Throttle down and gear up is recommended during $75 \%$ and 50 drawbar load.

\section{REFERENCES}

ASAE standards, 49th Ed. 20002a. EP496.2. Agricultural machinery management. St.Joseph, MMich.:ASAE.

Elashry, E. R. (2002). Tractive performance for 4-WD tractors under different tire-ballast combinations. Misr J. of Agric. Eng.19 (2):313-326.

El-Sayed, G. H. and M. M. Rushdie. (2002). Predicted VS. Measured tractor fuel consumption in soil-work operations. Misr J. Agric. Eng.19 (1):268-284.

Grisso, R. D., M.F. Kocher, and D.H. Vaughan. (2004). Predicting tractor fuel consumption. Applied Engineering in Agriculture 20(5):553561

Grisso, R. D., D.H. Vaughan and G.T. Roberson. (2006). Method for fuel prediction for specific tractor models. American Socity of Agricultural and Biological Engineers Paper No. 061089

Mohamed, A. A. and A. F. Bahnasy. (2005). Development of an electronic instrument to measure the fuel consumption of tractors. Misr J. Agric. Eng.22 (1):308-320.

Nada, A. A. (2003). Developing an electronic continuous mass fuel measuring system. The 11th Ann. Conf. Of Misr soc of Agric. Eng.,Oct.:273-282.

Romanov, F. F.; A. V. Palitsyn and V. A.Eviev. (2005). Accuracy of measuring fuel consumption of internal combustion engines with piston-type flow meters. Traktory i Sel'skokhozyaistvennye Mashiny, Issue: No.6 Page(s): 37-38 


\section{الملخص العربيى}

\section{التتبؤ بمعدل استهلاك الوقود للجرار والقدرة على قضيب الثد باستخدام اختبار ات معملية وحقلية}

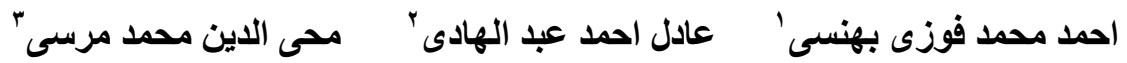

الهدف من البحث هو تحديد العو امل التى تؤثر على معدل استهلاك الوقود وقوة الثد على قضيب

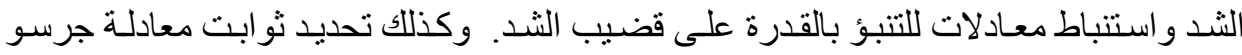

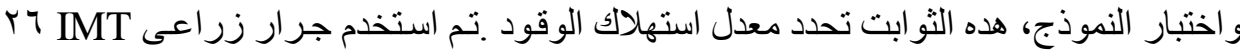

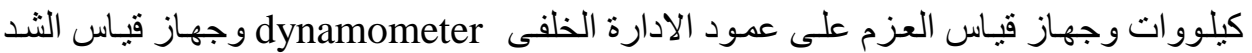

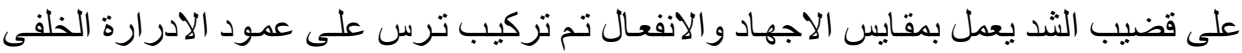
موصـل عليـه لاقط مغناطيسـى لقيـاس عدد لفـات عمـود الادارة الخلفى. تـم استخدم جـر ار آخـر للتحميل اثناء أجر اء التجارب لتغير الاحمال على قضيب الثد. تم قياس عدد لفات عمود الادارة

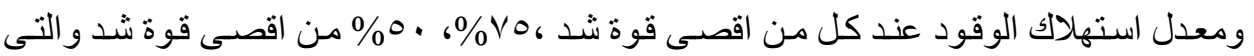

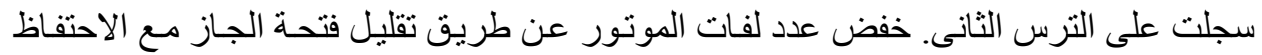

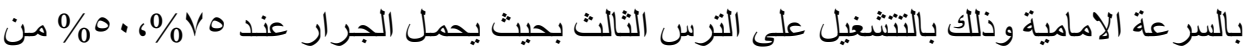

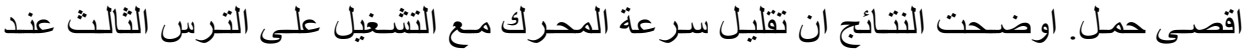

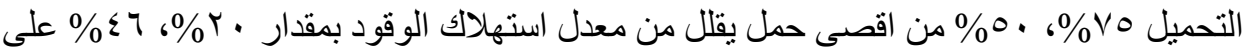

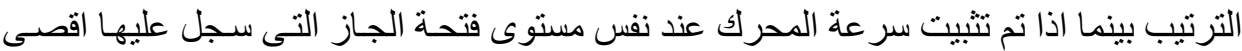

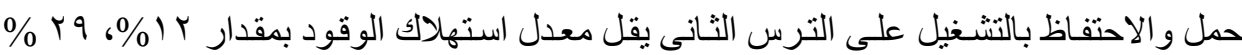

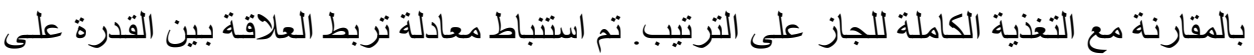

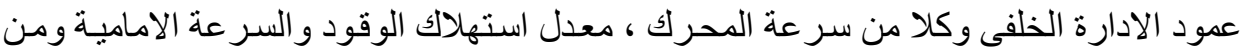

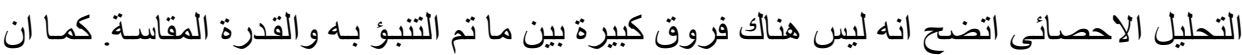

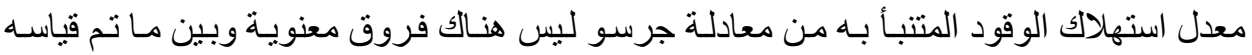
بجهاز قياس معدل استهلاك الوقود. 